\title{
PELATIHAN PENGEMBANGAN KOMUNIKASI PEMASARAN INDUSTRI PARIWISATA MELALUI PRODUK INOVATIF KREATIF DI KECAMATAN PARIGI KABUPATEN PANGANDARAN
}

\author{
Iwan Koswara, Dedi Rumawan Erlandia, dan Putri Trulline \\ Manajemen Komunikasi, Fakultas Ilmu Komunikasi, Universitas Padjadjaran
}

\begin{abstract}
ABSTRAK. Tujuan dari kegiatan PPM ini adalah untuk: (1) Memberikan pengetahuan dasar atas manfaat dan pentingnya komunikasi pemasaran bagi usaha kecil/industri kecil, dan menengah serta masyarakat pada umumnya, (2) Memberikan pengetahuan mengenai konsep pemasaran produk lokal orisinal, serta (3) Memberikan keterampilan praktis tentang pemilihan media komunikasi pemasaran (promosi) bagi pemasaran hasil industri produksi produk/jasa lokal. Peserta pelatihan ini adalah para usaha kecil, menengah, karang taruna/pemuda, serta masyarakat Desa Ciliang, Kecamatan Parigi Kabupaten Pangandaran. Adapun metode pelaksanaan PPM ini, melalui penyuluhan, dialog, dan diskusi, serta simulasi praktek langsung kegiatan komunikasi pemasaran industri pariwisata. Kegiatan PPM ini diharapkan akan memberikan manfaat langsung kepada masyarakat Desa Ciliang Kecamatan Parigi Khususnya, dan masyarakat Kabupaten Pangandaran pada umumnya, terutama para pelaku usaha kecil dan menengah. Kemampuan dan Keterampilan ini selanjutnya diharapkan dapat mendorong masyarakat untuk terus mengembangkan diri dan menjadi wirausahawan sehingga dapat meningkatkan taraf kehidupannya.Adapun target yang menjadi indikator pencapaian tujuan dari kegiatan PPM ini: Secara Kualitatif meningkatnya pemahaman dan kemampuan masyarakat dalam mengembangkan potensi daerahnya dalam melakukan pemasaran industri pariwisata barang/jasa melalui produk inovatif kreatif; Secara Kuantitatif meningkatnya aktivitas kegiatan komunikasi pemasaran pariwisata dalam menunjang peningkatan perekonomian masyarakat, melalui penciptaan wirausaha baru yang kreatif dan inovatif, dengan sumber daya lokal dari masyarakat Kabupaten Pangandaran
\end{abstract}

Kata kunci: Komunikasi Pemasaran Pariwisata; Produk Inovatif Kreatif

\section{PENDAHULUAN}

Peran komunikasi pemasaran menjadi semakin penting dalam pengembangan sektor pariwisata nasional di era Pasar Global saat ini. Pelaku usaha di sektor pariwisata tidak saja dituntut untuk memberikan pelayanan yang terbaik kepada wisatawan namun juga harus mampu bersaing dengan negara-negara lain di dunia. Potensi besar dalam bidang pariwisata yang dimiliki bangsa Indonesia, harus terus ditingkatkan untuk mendorong kemajuan ekonomi dan peningkatan kesejahteraan masyarakat. Pembangunan sektor pariwisata meliputi beberapa hal, diantaranya; pengembangan perwilayahan, pengelompokan objek dan daya tarik wisata; pengembangan produk wisata; pengembangan jaringan transportasi antar kawasan, daerah dan internasional; serta pengembangan pusat jaringan publik.

Kesesuaian antara pariwisata dengan perkembangan teknologi dan komunikasi memperlihatkan perlu adanya perpaduan bidang antara studi kepariwisataan (tourism study) dengan ilmu komunikasi (communication science) yang pada akhirnya akan menghasilkan konsep baru yakni Komunikasi Pariwisata (tourism communication). Secara garis besar tugas pokok yang diemban komunikasi pariwisata memiliki dua sasaran utama. Pertama, sasaran ekonomi, dimana komunikasi pariwisata harus dapat meningkatkan perekonomian, terutama dalam hal ini perekonomian yang berbasis kerakyatan. Indikator dari peningkatan ekonomi ini dapat dilihat dari peningkatan jumlah turis domestik maupun mancanegara yang datang ke berbagai tempat pariwisata baik itu wisata alam, wisata budaya, wisata sejarah, maupun wisata kuliner, yang selanjutnya dari peningkatan turis tersebut berdampak pada peningkatan kesejahteraan masyarakat, terutama masyarakat yang dekat dengan lokasi wisata.
Kedua, sasaran budaya. Sasaran ini dilaksanakan guna meningkatkan kecintaan dan pengetahuan masyarakat Indonesia akan budaya dan pariwisata yang kita miliki.

Konsep dasar dari pengembangan komunikasi pemasaran industri kreatif inovatif adalah adanya interaksi antara Pemerintah dan masyarakat, di mana peran masyarakat sangat dominan sebagai pihak yang memiliki kemampuan dan keinginan untuk mengembangkan produk atau potensi daerah yang dimilikinya. Pemerintah yang telah banyak mengetahui potensi dan kemampuan masyarakat, berfungsi untuk lebih memfasilitasi informasi tentang potensi pasar, membantu pengembangan produk supaya lebih menarik, membantu pemanfaatan teknologi supaya produk yang dihasilkan dapat lebih baik dan berkualitas serta membantu memberikan penyuluhan atau pelatihan bagi masyarakat, mengenai bagaimana seharusnya pengembangan produk dilakukan. Satu hal lagi yang penting adanya insentif serta penghargaan yang mendukung sehingga lebih dapat merangsang masyarakat untuk menciptakan dan mengembangkan produk lainnya menjadi inovatif dan kreatif..

Secara garis besar latar belakang dari pengembangan komunikasi pemasaran industri pariwisata adalah mempertimbangkan adanya konsentrasi dan kepadatan populasi di perkotaan sebagai akibat pola urbanisasi dan menurunkan populasi penduduk di pedesaan, sehingga pedesaan menjadi kehilangan penggerak dan gairah untuk bisa menumbuhkan roda kegiatan ekonomi. Untuk dapat menghidupkan kembali gerakan dan pertumbuhan ekonomi pedesaan, maka perlu dibangkitkan suatu roda kegiatan ekonomi yang sesuai dengan skala dan ukuran pedesaan dengan cara memanfaatkan potensi dan kemampuan yang ada di desa tersebut serta melibatkan para tokoh masyarakat setempat. Untuk mengurangi ketergantungan masyarakat desa yang terlalu tinggi 
terhadap Pemerintahan daerah maupun Pemerintah pusat, maka perlu diciptakan inisiatif dan semangat membangun dalam masyarakat desa, sehingga timbul rasa memiliki dan ingin membangun desa menjadi lebih baik (Sugiharto dan Rizal, 2008 : 3-5).

Produk inovatif kreatif sebagai suatu gerakan masyarakat yang secara integratif berupaya meningkatkan kesadaran masyarakat terhadap potensi dan kekayaan daerah, meningkatkan pendapatan para pelaku usaha dan masyarakat sekaligus meningkatkan rasa percaya diri dan kebanggaan terhadap kemampuan yang dimiliki masyarakat dan daerahnya. Sumber daya alam ataupun produk budaya lokal serta produk khas lokal yang telah dilakukan secara turun temurun dapat digali dan dikembangkan untuk menghasilkan produk bernilai tambah tinggi sesuai tuntutan dan permintaan pasar. Dengan pembagian peran yang jelas dari masing-masing pemangku kepentingan, adanya perencanaan yang baik, adanya tahapan kegiatan dan komitmen bersama pemangku kepentingan untuk memperkuat perekonomian masyarakat, maka peningkatan efektivitas pengembangan produk inovatif kreatif diharapkan dapat dicapai.

Berdasarkan uraian tersebut maka tahap awal yang perlu dilakukan terkait isu pengembangan dan peningkatan ekonomi masyarakat di Kecamatan Parigi Kabupaten Pangandaran, adalah perlunya program pengabdian pada masyarakat yang dituangkan dalam karya tulis dengan judul Pelatihan Pengembangan Komunikasi Pemasaran Industri Pariwisata Melalui Produk Inovatif Kreatif Di Kecamatan Parigi Kabupaten Pangandaran.

\section{METODE}

Mulyana(2003:145) mengatakan bahwa metodologi penelitian adalah proses, prinsip,dan prosedur yang kita gunakan untuk mendekati masalah dan mencari jawaban. Dengan kata lain, metodologi adalah suatu pendekatan umum untuk mengkaji sebuah topik. Sejalan dengan metode penelitian tersebut, maka metode pendekatan yang digunakan dalam pelatihan ini adalah metode pendekatan deskriptif, yaitu dengan memaparkan dan menjelaskan peran penting komunikasi pemasaran pariwisata, serta bagaimana merancang, menyusun, dan melakukan komunikasi pemasaran tersebut untuk mengirimkan informasi, serta menawarkan berbagai produk inovatif kreatif pariwisata sebagai daya tarik kepada para wiasatawan untuk berkunjung ke Pangandaran.

Pelatihan pengembangan komunikasi pemasaran industri pariwisata melalui produk inovatif kreatif bagi masyarakat Kabupaten Pangandaran sebagai daerah wisata, bertujuan untuk meningkatkan usaha ekonomi produktif dari masyarakatnya. Dalam pelaksanaannya dilakukan melalui beberaapa tahap yaitu; survei, tahap perencanaan, tahap pelaksanaan, tahap evaluasi dan tahap monitoring, dengan berbagai teknik pengumpulan data melalui observasi, wawancara, dan dokumentasi literatur.
Untuk pelaksanaan kegiatan ini Kami menghubungi Pihak terkait di Kabupaten Pangandaran untuk mendiskusikan topik yang akan disampaikan kepada peserta pelatihan dengan mengunjungi daerah tempat pengabdian yaitu Kabupaten Pangandaran. Tim survei berkunjung ke pemerintah otonomi daerah untuk bertemu dengan aparat pemerintah daerah dan tokoh masyarakat. Selain mengurus perijinan, juga dilakukan berbagai diskusi dengan para tokoh masyarakat, perwakilan masyarakat, serta aparat daerah. Tim PPM mencoba mengumpulkan data, baik melalui wawancara, pencatatan data, dokumentasi dan literatur untuk menggali berbagai informasi tentang halhal yang bisa dikembangkan di daerah ini. Sebagai daerah wisata Pangandaran merupakan tempat strategis untuk berwirausaha sekaligus memasarkan produk unggulan pariwisata, serta tempat-tempat pariwisata. Hasil survei dan pengumpulan data ini merupakan bahan yang sangat penting untuk mempersiapkan materi dan menjelaskan isi materi, pelatih (trainer), panitia yang terlibat, penentuan waktu, tempat, perhitungan anggaran, perlengkapan, dan peserta (khalayak sasaran).

Berdasarkan pemaparan di atas, maka metode pelaksanaan kegiatan Pelatihan Pengembangan Komunikasi Pemasaran Industri Pariwisata Melalui Produk Inovatif Kreatif Di Kecamatan Parigi Kabupaten Pangandaran ini dapat dipaparkan sebagai berikut :

1. Kelompok Sasaran

Kelompok atau khalayak sasaran adalah para pelaku UMKM produk unggulan lokal dari berbagai usia dan latar belakang, khususnya produk pangan olahan, kerajinan tangan dan cindera mata, termasuk juga anggota pemuda karang taruna kecamatan parigi. Peserta berasal dari desa Ciliang khususnya serta beberapa desa di Kecamatan Parigi Kabupaten Pangandaran. Teknisnya Kami bekerjasama dengan Camat dan Kepala Desa Kecamatan Parigi Kabupaten Pangandaran. PPM Prioritas ini berusaha untuk membangkitkan kesadaran peserta tentang potensi yang dimiliki baik sisi SDM maupun SDA, serta memberikan kemampuan dan keterampilan pengolahan produk inovatif, dan kemampuan komunikasi pemasaran.

2. Tahapan Kegiatan

(a) Metode Kegiatan

Kegiatan ini secara umum menggunakan pendekatan ceramah, diskusi, dan pelatihan atau workshop. Kemudian dilanjutkan dengan dengan dialog dengan para pelaku usaha, tokoth masyarakat, aparat Kepala Desa beserta staf desa di kantor Desa Ciliang, serta dialog dengan Camat dan stafnya di Kecamatan Parigi.

(b) Keterlibatan Mahasiswa

Kegiatan ini melibatkan mahasiswa peserta yang sedang melakukan KKNM di Desa Ciliang Kecamatan Parigi, Kabupaten Pangandaran sebagai bagian dari implementasi praktis materi yang pernah didapatkan di bangku kuliah. Mahasiswa selain 
membantu koordinasi dengan pihak desa, kecamatan, serta dengan para pelaku usaha juga turut aktif memperlancar proses selama kegiatan pelatihan ini berlangsung.

\section{(c) Partisipasi Masyarakat}

Pelatihan ini sangat memerlukan partisipasi aktif masyarakat secara umum dan pelaku UMKM di Kecamatan Parigi Kabupaten Pangandaran agar memahami pentingnya komunikasi pemasaran industri pariwisata melalui pengembangan produk inovatif kreatif.

Tabel 1. Tahap Kegiatan, Pelaku dan Peserta Kegiatan PPM

\begin{tabular}{|c|c|c|c|c|}
\hline \multirow{2}{*}{ No } & \multirow{2}{*}{ Kegiatan } & \multicolumn{3}{|c|}{ Keterlibatan dalam kegiatan } \\
\hline & & Dosen & Mahasiswa & Masyarakat \\
\hline 1. & Persiapan & $\begin{array}{l}\text { Perencana, } \\
\text { dan } \\
\text { Koordinator } \\
\text { Kegiatan }\end{array}$ & $\begin{array}{l}\text { Koordinator } \\
\text { Lapangan }\end{array}$ & Narasumber \\
\hline 2. & Pelaksanaan & $\begin{array}{l}\text { koordinator } \\
\text { Kegiatan, } \\
\text { Narasmber, } \\
\text { dan } \\
\text { Fasilitator }\end{array}$ & $\begin{array}{l}\text { Koordinator } \\
\text { Acara, } \\
\text { Fasilitator }\end{array}$ & $\begin{array}{l}\text { Penyedia } \\
\text { Tempat, } \\
\text { Narasumber, } \\
\text { dan Peserta }\end{array}$ \\
\hline 3. & Evaluasi & $\begin{array}{l}\text { Evaluator, } \\
\text { Konsultan, } \\
\text { Penulis } \\
\text { Laporan } \\
\text { Kegiatan }\end{array}$ & $\begin{array}{l}\text { Pendamping, } \\
\text { dan } \\
\text { Evaluator }\end{array}$ & $\begin{array}{l}\text { Penyedia } \\
\text { tempat, } \\
\text { Narasumber, } \\
\text { Peserta, dan } \\
\text { Evaluator }\end{array}$ \\
\hline
\end{tabular}

Terdapat beberapa indikator terkait kegiatan pelatihan pengembangan komunikasi pemasaran pariwisata melalui produk inovatif kreatif di Kecamatan Parigi Kabupaten Pangandaran.

\section{Indikator Sebelum Kegiatan (Baseline)}

a. Masih terbatasnya pemahaman masyarakat umumnya serta para pelaku UMKM di Kecamatan Parigi Kabupaten Pangandaran yang memahami pentingnya komunikasi pemasaran industri pariwisata melalui pengembangan produk inovatif kreatif.

b. Masih rendahnya pemahaman masyarakat pelaku UMKM di Kecamatan Parigi Kabupaten Pangandaran yang memahami pentingnya teknik pengolahan, pengemasan dan pemasaran dalam pengembangan produk unggulan lokal.

c. Masih banyak pelaku UMKM produk unggulan lokal di Kecamatan Parigi Kabupaten Pangandaran yang masih memasarkan produk unggulan lokal sebatas wilayah kota dan kabupaten sekitarnya, dan belum mampu menembus pasar regional maupun nasional.

Indikator pencapaian tujuan dari kegiatan ini adalah:

1. Secara Kualitatif meningkatnya pemahaman dan kemampuan masyarakat dalam mengembangkan potensi daerahnya dalam melakukan pemasaran industri pariwisata barang/ jasa melalui produk inovatif kreatif.

2. Secara kuantitatif meningkatnya a. aktivitas kegiatan komunikasi pemasaran pariwisata dalam menunjang peningkatan perekonomian masyarakat, melalui penciptaan wirausaha baru yang kreatif dan inovatif, dengan sumber daya lokal dari masyarakat Kabupaten Pangandaran.

b. bertambahnya pelaku UMKM produk unggulan lokal di Kecamatan Parigi Kabupaten Pangandaran yang memasarkan produk unggulan lokal yang mampu menembus pasar regional maupun nasional.

\section{Tabel 2. Indikator Capaian PPM}

\begin{tabular}{|c|c|c|c|}
\hline No & Indikator & $\begin{array}{c}\text { Base Line } \\
\text { (sebelum kegiatan) }\end{array}$ & $\begin{array}{c}\text { Pencapaian } \\
\text { Setelah Kegiatan }\end{array}$ \\
\hline 1. & $\begin{array}{l}\text { Masyarakat } \\
\text { yang memahami } \\
\text { Komunikasi } \\
\text { Pemasaran } \\
\text { industry } \\
\text { pariwisata secara } \\
\text { kuantitas }\end{array}$ & $\begin{array}{l}\text { Masih terbatasnya } \\
\text { jumlah masyarakat } \\
\text { pelaku UMKM } \\
\text { di Kecamatan } \\
\text { Parigi Kabupaten } \\
\text { Pangandaran } \\
\text { yang memahami } \\
\text { pentingnya } \\
\text { komunikasi } \\
\text { pemasaran industri } \\
\text { pariwisata melalui } \\
\text { produk inovatif } \\
\text { kreatif. }\end{array}$ & $\begin{array}{l}\text { Bertambahnya } \\
\text { masyarakat } \\
\text { pelaku UMKM } \\
\text { di Kecamatan } \\
\text { Parigi Kabupaten } \\
\text { Pangandaran } \\
\text { mengenai penting- } \\
\text { nya komunikasi } \\
\text { pemasaran industri } \\
\text { pariwisata melalui } \\
\text { produk inovatif } \\
\text { kreatif. secara } \\
\text { kuantitas. }\end{array}$ \\
\hline 2. & $\begin{array}{l}\text { Masyarakat } \\
\text { yang memahami } \\
\text { Komunikasi } \\
\text { Pemasaran } \\
\text { Industri } \\
\text { Pariwisata } \\
\text { secara kualitas }\end{array}$ & $\begin{array}{l}\text { Masih rendahnya } \\
\text { pemahaman } \\
\text { masyarakat } \\
\text { pelaku UMKM } \\
\text { di Kecamatan } \\
\text { Parigi Kabupaten } \\
\text { Pangandaran } \\
\text { yang memahami } \\
\text { pentingnya teknik } \\
\text { pengolahan, } \\
\text { pengemasan dan } \\
\text { pemasaran industri } \\
\text { pariwisata melalui } \\
\text { produk inovatif } \\
\text { kreatif. }\end{array}$ & $\begin{array}{l}\text { Meningkatnya } \\
\text { pemahaman } \\
\text { masyarakat } \\
\text { pelaku UMKM } \\
\text { di Kecamatan } \\
\text { Parigi Kabupaten } \\
\text { Pangandaran } \\
\text { yang memahami } \\
\text { pentingnya } \\
\text { komunikasi } \\
\text { pemasaran industri } \\
\text { pariwisata melalui } \\
\text { produk inovatif } \\
\text { kreatif secara } \\
\text { kualitas }\end{array}$ \\
\hline 3. & $\begin{array}{l}\text { Jumlah pelaku } \\
\text { UMKM produk } \\
\text { unggulan lokal } \\
\text { di Kecamatan } \\
\text { Parigi Kabupaten } \\
\text { Pangandaran } \\
\text { yang mampu } \\
\text { menembus pasar } \\
\text { regional maupun } \\
\text { nasional }\end{array}$ & $\begin{array}{l}\text { Masih banyak } \\
\text { pelaku UMKM } \\
\text { produk unggulan } \\
\text { lokal di Kecamatan } \\
\text { Parigi Kabupaten } \\
\text { Pangandaran yang } \\
\text { hanya memasarkan } \\
\text { produk unggulan } \\
\text { lokal sebatas } \\
\text { wilayah kota } \\
\text { dan kabupaten } \\
\text { sekitarnya, dan } \\
\text { belum mampu } \\
\text { menembus pasar } \\
\text { regional maupun } \\
\text { nasional. }\end{array}$ & $\begin{array}{l}\text { Bertambahnya } \\
\text { jumlah pelaku } \\
\text { UMKM produk } \\
\text { unggulan lokal } \\
\text { di Kecamatan } \\
\text { Parigi Kabupaten } \\
\text { Pangandaran } \\
\text { yang mampu } \\
\text { menembus pasar } \\
\text { regional maupun } \\
\text { nasional secara } \\
\text { kuantitas. }\end{array}$ \\
\hline
\end{tabular}

Sumber: Hasil Survei Di Kecamatan Ciliang Kabupaten Pangandaran 2018

\section{HASIL DAN PEMBAHASAN}

Kegiatan pengembangan komunikasi pemasaran pariwisata melalui produk inovatif kreatif di Kecamatan Parigi Kabupaten Pangandaran tidak dapat dilakukan dalam waktu singkat, oleh karena itu kegiatan pengembangan komunikasi pemasaran yang dilakukan saat KKNM merupakan awal kegiatan yang harus ditindak lanjuti 
dengan proses pendampingan sampai masyarakat dapat mandiri, dan mampu membentuk kelompok-kelompok usaha, dengan membangun berbagai produk inovatif sebagai produk unggulan wisata Pangandaran.

Beberapa hasil yang dapat dicapai dalam kegiatan PPM Prioritas ini adalah sebagai berikut:

a. Keterlibatan Aktif Masyarakat dalam Kegiatan PPM

Keterlibatan masyarakat dalam kegiatan pelatihan pengembangan komunikasi pemasaran melalui produk inovatif kreatif merupakan langkah awal untuk memberikan pengetahuan baru dan pengembangan kesadaran mereka terkait dengan komunikasi pemasaran pariwisata. Setiap perubahan harus diawali dengan kesediaan masyarakat untuk mengembangkan pengetahuan dan kesadarannya demi kehidupan yang lebih baik dan sejahtera. PPM Priotitas yang dilakukan di Kecamatan Parigi, bertempat di Aula Desa Ciliang Kabupaten Pangandaran dihadiri oleh 42 peserta, para aparat desa, serta kecamatan Parigi. Mereka semua, sangat antusias dalam mendukung terhadap kegiatan ini.

b. Munculnya Pengetahuan, Keterampilan, dan Kesadaran Masyarakat

Melalui pelatihan yang dilaksanakan ini, telah berhasil memberikan bekal pengetahuan dan keterampilan mengenai pentingnya komunikasi pemasaran pariwisata, dalam memasarkan produk inovatif kreatif sebagai produk unggulan pariwisata Kabupaten Pangandaran.

c. Terjadinya Sharing/Dialog Mengenai Strategi Komunikasi Pemasaran Pariwisata.

Saat kegiatan pelatihan berjalan, terjadi interaksi langsung, berupa sharing dan dialog terkait dengan kegiatan komunikasi pemasaran pariwisata. Dari proses sharing dan dialog ini ditemukan beberapa informasi yang mereka butuhkan, mereka pun meyadari tentang kesulitan melakukan kegiatan komunikasi pemasaran ini. Mereka mengungkapkan bahwa mereka butuh bagaimana teknik melakukan komunikasi pemasaran pariwisata tersebut, media yang digunakan, bagaimana merancang strategi komunikasi pemasaran, serta bagaimana melakukan pengolahan mengenai potensi produk yang dimiliki, sehingga menjadi produk inovatif dan kreatif, sebagai produk unggulan pariwisata.

Tumbuhnyajiwa wirausaha merupakan faktoryang penting untuk membantu menanggulangi, mengurangi angka kemiskinan, dan pengangguran. Oleh karena itu kemampuan dan keterampilan berwirausaha diharapkan dapat membuat para peserta mendirikan usahanya sendiri dan bahkan dapat menyediakan lapangan pekerjaan bagi orang lain. Kemampuan dan keterampilan kewirausahaan ini dapat dibangun dan dikembangkan di masyarakat, sebagaimana dikatakan oleh Peters (1995 : 13) bahwa
" Entrepreneurs are not born they are developed". Artinya, tidak ada seorangpun yang dilahirkan langsung mempunyai kemampuan berwirausaha, tetapi kemampuan itu harus melalui pendidikan dan pengalaman.

Pangandaran sebagai daerah wisata yang menjadi tujuan bagi para turis baik domestik maupun manca negara, mempunyai potensi yang menjajnjikan untuk dikembangkan. Masyarakat asli sebagai putra daerah yang berasal dari Pangandaran, diharapkan mampu mengelola dan mengembangkan potensi wilayah-wilayah mereka, namun demikian kondisi yang ada memperlihatkan bahwa masyarakat asli daerah tersebut cenderung tersisih karena mereka kalah bersaing dengan para pendatang. Disamping permasalahan keuangan, permasalahan yang lainnya adalah karena kurangnya pengetahuan tentang kewirausahaan, masalah terkait kesulitan untuk memasarkan produk-produknya. Tim PPM tergerak untuk mengadakan pelatihan keterampilan tentang komunikasi pemasaran pariwisata. Pelatihan keterampilan ini sangat penting untuk mendorong dan memotivasi masyarakat asli daerah tersebut untuk menjadi wirausahawan dan mengembangkan usahanya yang sudah mereka jalani. Hasil dari PPM tersebut memperlihatkan bahwa mereka mempunyai semangat untuk menjalankan usahanya.

Pelatihan tentang komunikasi pemasaran pariwisata dengan peserta pelaku usaha wisata, karang taruna, masyarakat umum, serta aparat desa dan kecamatan, memberikan tantangan tersendiri buat pemateri. Para peserta yang hadir harus membawa manfaat dari pelatihan ini. Sebagai perwakilan dari masing-masing kelom-poknya, mereka akan berbagi ilmu dan keterampilan dengan masyarakat yang tidak hadir. Para pelaku usaha mendapatkan ilmu tentang bagaimana mengemas produk-produk usahanya, sekaligus mendapatkan ilmu tentang strategi memasarkannya, diantaranya melakukan kegiatan promosi, penggunaan media komunikasi (promosi), termasuk juga bagaimana mengadakan pameran dan event atau acara kegiatan tuk mempromosikan produk inovatif sebagai daya tarik wisata Pangandaran. Hasil diskusi menunjukkan, di wilayah Pangandaran, belum ada sebuah kegiatan berskala besar yang pelaksanaannya berulang, fenomenal dan dikelola secara profesional oleh masyarakat asli daerah tersebut. Oleh karena itu, pelatihan komunikasi pemasaran pariwisata, memerlukan pengelolaan yang sangat serius. Pangandaran sebagai daerah wisata, tentunya harus dijaga keindahan, kebersihan, keamanan, kenyamanannya, agar supaya para wisatawan merasa senang. Para pengelola wisata harus mampu memasarkan daerahnya supaya semakin banyak wisatawan yang datang, baik wisatawan domestik maupun manca negara. Kotler (2012 :64) menekankan bahwa strategi pemasaran sebagai alat fundamental yang direncanakan untuk mencapai tujuan perusahaan dengan mengembangkan keunggulan bersaing yang berkesinambungan melalui pasar yang dimasuki dan program pemasaran yang digunakan untuk melayani pasar sasaran tersebut. Dari definisi diatas dapat diambil benang 
merahnya bahwa untuk bisa mencapai tujuan perusahaan diperlukan strategi pemasaran yang direncanakan dan berkesinambungan.

Hasil dari pelatihan tentang komunikasi pemasaran pariwisata menunjukkan bahwa para peserta memiliki hasrat yang kuat untuk berkembang. Mereka berusaha menyerap ilmu yang didapat secara maksimal. Hal ini bisa dilihat dari respon melalui instrumen terukur seperti pernyataan melalui pre test dan post test dan lembar evaluasi. Selain itu, dapat dilihat dari respon selama pelatihan. Tim PPM menyadari tuntutan dari hasil yang didapat ini. Kami berkewajiban untuk terus mendampingi agar masyarakat sasaran tetap bersemangat dan mampu mewujudkan harapannya.

Pangandaran sebagai tourism area harus dinikmati oleh putra-putri daerah tersebut. Mereka harus mampu menjaga wilayahnya dengan mengembangkan dan menerapkan strategi komunikasi pemasaran yang tepat. Surachman (20018:1) menjelaskan bahwa pemasaran adalah suatu proses kegiatan mulai dari penciptaan produk atau jasa, menawarkan, dan menyerahkan kepada konsumen dan atau pihak lain. Artinya, daerah wisata Pangandaran harus mampu menciptakan produk-produk yang menarik bagi wisatawan, seperti adanya event-event yang menarik dan paket-paket wisata yang menarik. Para pengelola harus mampu memasarkan produk-produk tersebut melalui cara yang menarik, inovatif dan kreatif.

Kotler (2012) mengatakan bahwa "Pemasaran modern memerlukan lebih dari sekedar mengembangkan produk yang baik, menawarkannya dengan harga yang menarik, dan membuatnya mudah di dapat oleh pelanggan sasaran" selanjutnya ia berkata "Perusahaan harus juga berkomunikasi dengan para pelanggan yang ada sekarang dan pelanggan potensial, pengecer, pemasok, pihak-pihak yang memiliki kepentingan pada perusahaan tersebut, dan masyarakatumum".Lanjutnyalagi:"setiapperusahaan tidak dapat menghindari peranannya sebagai komunikator dan promotor. Bagi sebagian besar perusahaan, pertanyaannya bukanlah apakah akan melakukan komunikasi tersebut atau tidak, tetapi lebih pada apa yang akan dikomunikasikan, kepada siapa, dan seberapa sering".

Fill (1999: 3) defined marketing communications as 'the process by which the marketer develops and presents an appropriate set of communications stimuli to a defined target audience with the intention of eliciting a desired set of responses". Fill mengemukakan bahwa komunikasi pemasaran merupakan proses dimana pemasar mengembangkan dan menyajikan sekumpulan rangsangan komunikasi yang sesuai yang ditujukan kepada khalayak sasaran yang telah ditetapkan dengan tujuan untuk memunculkan sekumpulan tanggapan yang diinginkan. Sejalan dengan pernyataan tersebut, maka pemasaran pariwisata adalah seluruh kegiatan untuk mempertemukan permintaan (demand) dan penawaran (supply), sehingga pembeli mendapat kepuasaan dan penjual mendapat keuntungan maksimal dengan resiko seminimal mungkin. Pembeli dalam kegiatan pariwisata yaitu para wisatawan, sedangkan penjual yakni pihak pengelola kawasan pariwisata tersebut. Hal ini tidak lepas dari peran komunikasi pemasaran di dalamnya. Syam (2010 : 16). Komunikasi pemasaran dapat juga dinyatakan sebagai kegiatan komunikasi yang ditujukan untuk menyampaikan pesan kepada konsumen, yang dalam aspek ini adalah bagaimana para pelaku usaha dan para pengelola pariwisata, melakukan aktivitas komunikasi pemasaran pariwisata melalui produk-produk yang mereka hasilkan.

Berdasarkan pemaparan tersebut di atas, maka kegiatan komunikasi pemasaran pariwisata merupakan faktor yang sangat penting dilakukan mengingat daerah Kabupaten Pangandaran merupakan daerah destinasi wisata, selain memiliki kekayaan alam (sumber daya alam) yang luar biasa juga sumber daya manusia, yakni para pelaku usaha, maupun masyarakat yang perlu dibina, sehingga mereka mampu mandiri melakukan pengelolaan industri pariwisata melalui pengelolaan produk inovatif kreatif, baik itu produk kuliner, maupun produk barang dagangan (merchandise), sehingga selain dapat menjadi daya tarik wisata, juga dapat membantu tingkat perekonomian masyarakat kabupaten pangandaran.

\section{SIMPULAN}

Berdasarkan hasil lapangan dan pembahasan yang telah dipaparkan sebelumnya, maka dapat ditarik simpulan berikut ini: Pelatihan yang telah dilakukan ini selain memberikan bekal pengetahuan dan keterampilan juga telah berhasil menyadarkan masyarakat betapa pentingnya kegiatan komunikasi pemasaran pariwisata dalam menawarkan produk inovatif kreatif yang dapat mendukung pemasaran pariwisata daerah, sekaligus pula dapat menunjang peningkatan perekonomian masyarakat; Pelatihan ini telah memberikan bekal pengetahuan dan keterampilan bagaimana mengolah, dan memanfaatkan barang produksi lokal berasal dari daerah Pangandaran, menjadi produk inovatif kreatif meskipun dalam skala terbatas, dalam mendukung industri pariwisata pangandaran; Pelatihan pengembangan komunikasi pemasaran pariwisata ini , telah memberkan pengetahuan dan keterampilan bagaimana merancang, merencanakan dan melakukan pemilihan serta penggunaan media komunikasi dan promosi industri pariwisata.

\section{DAFTAR PUSTAKA}

Arikunto, Suharsimi.2006. Prosedur Penelitian Suatu Pendekatan Praktik. Jakarta: Rineka Cipta.

Badan Pusat Statistik Kabupaten Pangandaran. 2017.

Boedisetio. Kawi. 2013. Gerakan One Village One Product (OVOP) di Indonesia. Jakarta: BPPT.

Bungin, Burhan. 2003. Analisis Data Penelitian Kualitatif. Jakarta: PT Rajagrafindo Persada. 
Creswell, John W. 1998. Qualitative Inquiry and Research Design: Choosing Among Five Traditions. California: Thousand Oaks, SagePublications, Inc.

Denzin, Norman K. dan Guba, Egon. 2001. Teori dan Paradigma Penelitian Sosial; Pemikiran dan Penerapannya, Penyunting: Agus Salim. Yogyakarta: PT Tiara Wacana.

Fill, Chris. 1999. Marketing Communication, Frameworks, Theories and Applications, London Prentice Hall.
Kotler, Philip dan Gary Armstrong, 2012. Principle of Marketing. Edisi 14. New Jersey: Pearson Prentice Hall.

Mulyana, Deddy. 2003. Metodologi Penelitian Kualitatif: Paradigma Baru Ilmu Komunikasi dan Ilmu Sosial lainnya. Bandung : Remaja Rosdakarya.

Rakhmat, Jalaluddin. 2005. Psikologi Komunikasi. Bandung: Remaja Rosdakarya.

Ritzer, George. 2008. Sociological Theory. New York: McGraw-Hill.

Syam, Winangsih. Nina. 2010. Komunikasi Pariwisata Di Indonesia. Bandung. News Publishing. 